\title{
The political and legislative history that underlies the farm bill
}

\author{
Review by Sheila Fleischhacker, Georgetown University*
}

Review of The Fault Lines of Farm Policy: A Legislative and Political History of the Farm Bill by Jonathan Coppess. (2018). Published by University of Nebraska Press. Available in hardcover and eBook (PDF and EPUB); 504 pages. Publisher's website: https://www.nebraskapress.unl.edu/ university-of-nebraska-press/9781496205124/

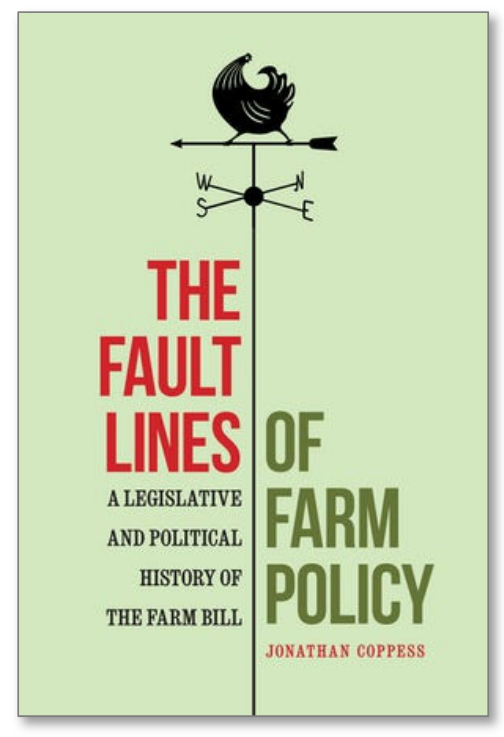

Submitted February 14, 2019 / Published online July 9, 2019

Citation: Fleischhacker, S. (2019). The political and legislative history that underlies the farm bill [Book review]. Journal of Agriculture, Food Systems, and Community Development, 9(1), 137-138. https://doi.org/10.5304/jafscd.2019.091.005

Copyright (C) 2019 by the Author. Published by the Lyson Center for Civic Agriculture and Food Systems. Open access under CC-BY license.

$I^{n}$ n The Fault Lines of Farm Policy, Jonathan Coppess explores the evolution of the farm bill through the political and congressional interests representing the United States' three main commodity production regions: the South, the Midwest, and the Great Plains. Coppess combines analysis of his direct involvement in the legislative and executive branches' farm bills in 2008 and 2014 with extensive historical, contemporary political, and legislative analyses in his current academic role. Coppess served in the U.S. Senate and at the U.S. Department of Agriculture (USDA) from 2006 to 2013. These rich descriptions explain

\footnotetext{
* Sheila Fleischhacker, PhD, JD, is an adjunct professor of law at Georgetown University, where she teaches a first-of-its-kind nutrition law and policy course. She also is developing a course book that synthesizes key law and policy approaches from historical and contemporary perspectives across the globe to improving healthy eating and reducing nutritionrelated noncommunicable diseases and food insecurity. She can be contacted at sheilafly9@gmail.com.
}

the underpinnings of congressional efforts and identify the drivers of American farm policy development.

Organized in chronological order, starting with the origins of farm policy from 1909 through the 2014 farm bill, each chapter (dedicated to one farm bill) provides a thorough presentation of the key political and legislative history of the era. Coppess concludes each chapter with his own thoughts and perspectives, which helps bridge the legislative process of one farm bill to its implementation to the next round of the farm bill's policy development. This is particularly useful as he interweaves the book's title and overarching theme of how "disputes among the South, the Great Plains, and the Midwest over farm policy form the primordial fault line and have been the defining characteristic of the debate throughout [farm policy's] history" (p. 8).

That is, Coppess focuses on the origins and evolution of the intense regional fights among the 
three major commodities produced in these regions: cotton, wheat, and corn. He discusses how these regions formed the original farm coalition and have continued to play dominant roles throughout farm policy development. Coppess details the political and congressional interests representing these commodities farm bill by farm bill, including coalition-building strategies, external and internal pressures on each coalition and its fault lines, and the impacts of commodity prices. These explorations of political fault lines and the reflections on how incredibly resilient these coalitions have been over the last eight decades provide insights on the recently passed 2018 farm bill, as well as metrics of effective policy outcomes of future farm bills.

Coppess noted the following three books served as great resources as he was writing this book: Bill Winder's The Politics of the Food Supply: U.S. Agricultural Policy in the World Economy; John Mark Hansen's Gaining Access: Congress and the Farm Lobby, 1919-1981; and Murray R. Benedict's Farm Policies in the United States, 1790-1950: A Study of Their Origins and Development. Each of these books is invaluable to those interested in farm policy history; notwithstanding, The Fault Lines of Farm Policy provides a contemporary synthesis of these works and a more focused analysis on the role of commodity coalitions. Coppess also used legislative history to help interpret statutory language, including reviewing debates on the House and Senate floors, committee reports, testimony at hearings, and other public records. In addition, he examined media sources like Keith Good on FarmPolicy.com and Politico news reports. He also drew from his personal knowledge, particularly of the 2008 and 2014 farm bills. These diverse sources of political and legislative histories ensure that the reader understands how actions on the Hill were being perceived by key stakeholders and the overall public at the time.

Increasingly, authors are tackling the United States' farm policy, targeting a range of audiences from agriculture scholars to consumers. This book does not provide extensive comparison of farm policy in other countries nor how regional coalitions of commodity production interests influence farm policy outside the U.S. Given the commodity coalition emphasis, this book consistently explains farm policies' impacts on crop prices. More recent coalitions impacting farm bill debates, such as those between public health and anti-hunger coalitions on the best ways to strengthen the role of nutrition in the USDA Supplemental Nutrition Assistance Program (SNAP; formerly food stamps) are briefly noted, particularly in the discussion of the 2014 farm bill. Without question, Coppess instills in readers the importance of reflecting on the origins and evolution of the farm policy before, during, and after embarking on future farm policymaking processes.

I would recommend this book for scholars on agriculture, as well as those working in research, policy, and practice on farm bill-related manners. The book feels like a textbook due to the extensive detail it provides, but chapters on the origin and early eras of farm policy might need to be combined or summarized for teachers wanting to invest a significant portion of their class on contemporary policy matters. I also would recommend this book to any academic or practitioner focused on the role of coalitions in the legislative process- - how to build them, modify them, and understand their short- and long-term impacts. 